\title{
Comparison of resilience and subjective well-being to fathers and mothers who have postlingual deafness children
}

\author{
Destalya Anggrainy $^{1}$, Efi Fitriana ${ }^{2}$, Aulia Iskandarsyah $^{3}$, Juke Siregar ${ }^{4}$ \\ ${ }^{1234}$ Fakultas Psikologi, Universitas Padjadjaran
}

\section{Article Info \\ Article history: \\ Received Aug $17^{\text {th }}, 2019$ \\ Revised Oct $16^{\text {th }}, 2019$ \\ Accepted Dec 30 $0^{\text {th }}, 2019$}

\section{Keyword:}

Resilience

Subjective well-being

Postlingual deafness children

Father and mother

\begin{abstract}
This study aims to compare the resilience and subjective well-being of fathers with mothers who have postlingual deafness children. Participants in this study were 336 parents (168 fathers and 168 mothers) who had postlingual deafness children, were biological fathers and mothers of postlingual deafness children, lived with their partners and children who experienced postlingual deafness, were able to communicate verbally and in writing using Indonesian good, domiciled in West Java. This research uses a comparative study approach. The instrument used in this study is the CD-RISC which has been modified into Indonesian and subjective well-being instruments constructed by researchers based on the Diener theory. The findings in this study reveal that there are significant differences in resilience and subjective well-being between fathers and mothers who have postlingual deafness children. Based on the average resilience and average subjective well-being seen in the group, the group of fathers who have postlingual deafness children has a higher score compared to the group of mothers who have postlingual deafness children.
\end{abstract}

C 2019 The Authors. Published by Indonesian Institute for Counseling, Education and Therapy (IICET). This is an open access article under the CC BY license (https://creativecommons.org/licenses/by/4.0/)

\section{Corresponding Author:}

Destalya Anggrainy,

Email: destalyaamp@gmail.com

\section{Pendahuluan}

Studi terkini dalam bidang psikologi mulai mencoba untuk mengembangkan aspek positif yang dimiliki oleh individu, menurut (Seligman, M. E. P., Ernst, R. M., Gillham, J., Reivich, K., \& Linkins, 2009) selama ini psikologi lebih cenderung memfokuskan pada sisi negatif dari manusia sehingga individu harus segera diobati dan dicarikan solusinya. Dengan adanya terapi, pengobatan dan pencarian solusi diharapkan dapat memberi manfaat dalam penyelesaian masalah mental individu, namun seringkali membuat individu lupa untuk mengupayakan hidup yang bermakna dan bahagia, sehingga stres dan frustasi yang dialami individu cenderung meningkat. Selain itu, kenyataannya dalam diri individu terdapat dua sisi yang berlainan yaitu sisi negatif dan sisi positif. Psikologi positif lebih cenderung menaruh perhatian besar pada sisi-sisi positif individu. (Seligman, M. E. P., Ernst, R. M., Gillham, J., Reivich, K., \& Linkins, 2009) juga meyakini bahwa dengan membangun kualitas-kualitas positif pada hidup individu, maka individu dapat mengoptimalkan dirinya dan dapat terlindungi dari ketidakberdayaan.

Pendekatan dalam psikologi positif ini sangat berguna diterapkan bagi siapa saja, termasuk bagi orangtua yang memiliki anak berkebutuhan khusus. Kehadiran anak berkebutuhan khusus di tengah keluarga dapat memberikan efek yang cukup mendalam, seperti pada orangtua yang memiliki anak dengan hambatan pendengaran. Di dunia sekitar 466 juta orang mengalami hambatan pendengaran dan 34 juta diantaranya merupakan anak-anak. Individu dengan hambatan pendengaran merupakan individu yang kehilangan pendengaran baik sebagian (hard of hearing) maupun seluruhnya (deaf) sehingga menyebabkan pendengarannya tidak memiliki nilai fungsional di dalam kehidupan sehari-hari yang membawa dampak terhadap kehidupannya secara kompleks (Turnbull, A. A., Rutherford, H., Wehmeyer., M. L., \& Shogren, 2013). 
Individu dengan hambatan pendengaran biasanya disebut tunarungu, hambatan pendengaran tersebut mengakibatkan individu tersebut tidak dapat menangkap berbagai rangsangan, terutama melalui indera pendengarannya, dengan kata lain individu tunarungu adalah individu yang kehilangan seluruh atau sebagian daya pendengarannya, sehingga mengalami gangguan berkomunikasi secara verbal.

Hambatan pendengaran dapat disebabkan karena berbagai hal seperti genetik, komplikasi saat lahir, penyakit tertentu, infeksi telinga kronis, penggunaan obat-obatan tertentu dan juga paparan kebisingan yang berlebihan (WHO, 2019). Kehilangan pendengaran dapat mempengaruhi kemampuan bicara pada individu, tergantung pada kapan kehilangan pendengaran itu terjadi. Menurut (Turnbull, A. A., Rutherford, H., Wehmeyer., M. L., \& Shogren, 2013), kehilangan pendengaran berdasarkan waktunya dibagi menjadi 2 yaitu (1) prelingual deafness dan (2) postlingual deafness. Individu yang mengalami prelingual deafness adalah individu yang mengalami kehilangan pendengaran saat masih bayi atau saat dilahirkan. Sedangkan pada individu yang mengalami postlingual deafness adalah individu yang mengalami hambatan pendengaran setelah mereka memeroleh bahasa lisan sebelum pendengaran mereka berkurang, hal ini biasanya terjadi pada saat anak usia 5 tahun. Penyebab seorang anak mengalami postlingual deafness karena adanya efek samping dari obat-obatan dan penyakit. Pada kebanyakan individu dengan postlingual deafness akan kehilangan pendengaran secara bertahap.

Bagi anak yang mengalami hambatan pendengaran akan membawa dampak pada pendidikan yang diperolehnya, sementara pendidikan memiliki peran penting dalam kemampuan berpikirnya. Masa kanakkanak merupakan masa yang penting dalam proses pendidikan sebagaimana yang dikemukakan oleh Bloom (Anderson, L.W., \& Krathwohl, 2010) bahwa perkembangan intelektual pada individu berlangsung sebelum usia empat tahun. Sedangkan perkembangan intelektual pada anak dibantu oleh seluruh fungsi indera pada anak seperti indera penglihatan, pendengaran, peraba dan sebagainya. Apabila salah satu indera ini mengalami hambatan maka berdampak pada pendidikannya. Penguasaan bahasa pada anak yang mendengar terjadi secara wajar, sejak berada di lingkungan keluarga selama usia balita. Pada usia empat tahun, pada umumnya anak sudah memasuki tahap purnabahasa (postlingual) yaitu mengenal dan memahami lambang, bahasa serta tanpa disadari sudah mampu menerapkan aturan bahasa yang digunakan di lingkungannya. Namun akan berbeda apabila anak tersebut mengalami postlingual deafness, ketika anak tersebut sedang mengenal bahasa dan ternyata mengalami kemunduran dalam fungsi pendengarannya maka diperlukan layanan khusus yang sistematis, terarah dan berkesinambungan untuk membuat anak tersebut tetap dapat memperoleh pendidikan dan hal tersebut diperoleh utamanya dari lingkungan keluarga. (Yusuf, 2012) mengemukakan bahwa orangtua adalah bagian terpenting dalam lingkungan anak dan dapat menentukan bagaimana anaknya kelak. Nilai, sikap dan berperilaku anak merupakan hasil dari interaksi anak dengan orangtuanya. Dukungan dan peran serta orangtua dan keluarga sangat diperlukan bagi perkembangan anak yang optimal, terlebih bagi anak yang berkebutuhan khusus.

Ketika orangtua mengetahui bahwa anak mereka mengalami penurunan dalam fungsi pendengarannya (postlingual deafness), mereka pada awalnya merasa sedih, marah dan bahkan kecewa, namun sebagai orangtua, mereka harus tetap bangkit dan bertahan karena orangtua memiliki fungsi yang sangat penting dalam memenuhi kebutuhan anak, menanamkan kehidupan beragama, memberikan pendidikan, perlindungan dalam masa perkembangan anak, menjadi penghubung dalam kehidupan sosial anak, memperhatikan perasaan anak dan memberikan rasa nyaman, serta memberikan nafkah demi keberlangsungan hidup anaknya (Yusuf, 2012). Selain itu menurut (Santrock, 2012) peran orangtua pada masa anak adalah sebagai manajerial, terutama dalam perkembangan sosioemosional anak. Sebagai manajer, orangtua memberikan ruang kepada anak melakukan kontak sosial dengan teman sebaya, teman dan orang dewasa namun tetap dalam pemantauan yang efektif terhadap anak seperti mengawasi pilihan anak tentang tempat sosial, aktivitas dan teman. Dalam menjalankan fungsi dan peran tersebut tidaklah mudah, terlebih lagi jika peran tersebut diterapkan terhadap anak yang mengalami postlingual deafness. Salah satu pendekatan yang berguna untuk diterapkan dalam mendidik dan membesarkan anak yang mengalami postlingual deafness adalah dengan menerapkan psikologi positif, yaitu pandangan bahwa individu dapat menjadi yang terbaik dan dapat menjalani hidup dengan bahagia dan optimis, bagaimanapun kondisinya. Psikologi positif ini sangat berguna bagi orangtua untuk mampu bangkit kembali ditengah situasi yang menekan dan merasa sejahtera dalam hidupnya.

Kemampuan untuk dapat beradaptasi dengan baik dan mampu berfungsi secara baik di tengah situasi yang menekan dan banyak halangan serta rintangan disebut resiliensi menurut Connor \& Davidson (Azari \& Mohammadi, 2016). Oleh karenanya, orangtua membutuhkan kemampuan resiliensi ini, apabila orangtua 
yang memiliki anak postlingual deafness mempunyai jiwa resilien, maka mereka akan mampu terhindar dari berbagai resiko negatif yang mengganggu psikologisnya, atau minimal mereka dapat kembali pulih dan dapat beradaptasi secara positif seperti biasanya, hal tersebutlah yang selalu diupayakan orangtua agar terhindar dari kondisi terpuruk dan stres, keterampilan mengelola stres yang baik membuat mereka mampu beradaptasi secara positif dengan masalahnya dan mengembangkan diri secara optimal (Turnbull, A. A., Rutherford, H., Wehmeyer., M. L., \& Shogren, 2013). Apabila orangtua mampu memiliki jiwa resilien maka orangtua diharapkan dapat juga sejahtera dalam hidupnya. Kesejahteraan subjektif merupakan salah satu komponen yang paling penting bagi individu untuk mengevaluasi kehidupannya yang mencakup kepuasan hidup dan kebahagiaan (Diener \& Ryan, 2009).

Menurut beberapa hasil penelitian sebelumnya, resiliensi ada kaitannya dengan kesejahteraan subjektif individu seperti pada penelitian yang dilakukan oleh (Amini et al., 2012) yang membandingkan kesejahteraan subjektif, resiliensi dan burnout pekerjaan antara perawat di Critical Care Units (CCU) dan unit lainnya di rumah sakit Tehran, mereka menemukan bahwa perawat CCU memiliki kesejahteraan subjektif dan resiliensi yang rendah dibandingkan dengan perawat di unit lainnya dan mereka menemukan bahwa terdapat hubungan positif antara resiliensi dan kesejahteraan subjektif diantara para perawat tersebut. (Kimiaye, S. A., Mehrabi, H., \& Mirzaei, 2010) juga melakukan penelitian mengenai kualitas hidup orangtua yang memiliki anak berkebutuhan khusus dan hasilnya menunjukan bahwa adanya perbedaan kualitas hidup pada orangtua yang memiliki anak berkebutuhan khusus yang ditentukan oleh jenis kebutuhan khususnya.

Penelitian yang dilakukan oleh (Monjezi \& Naderi, 2016) menunjukkan perbedaan yang signifikan pada kesejahteraan subjektif antara dokter pria dan dokter wanita di Ahvaz, Iran serta menemukan bahwa stres dan peristiwa hidup yang tidak menyenangkan dapat mempengaruhi kesejahteraan subjektif pada individu. (Norlin \& Broberg, 2013) mengungkapkan dalam penelitiannya bahwa Ibu yang memiliki anak berkebutuhan khusus merasa sangat bertanggung jawab atas pengasuhan terhadap anaknya sehingga hal ini yang membuat Ibu lebih cenderung memiliki tingkat stres yang tinggi dibandingkan Ayah. (Findler et al., 2016); (Gardiner \& Iarocci, 2012) juga menyatakan bagi Ibu yang memiliki anak berkebutuhan khusus mengalami emosi yang kurang stabil karena mereka menghayati kondisi anaknya sebagai sesuatu yang menekan secara psikologis di dalam kehidupannya. Berdasarkan penelitian-penelitian tersebut, baik resiliensi dan kesejahteraan subjektif merupakan hal yang berperan penting dalam diri individu, begitupula bagi orangtua yang memiliki anak postlingual deafness.

Perkembangan resiliensi pada individu dipengaruhi oleh karakteristik individu di setiap level usia, pengalaman, proses belajar baik secara sadar maupun tidak, disamping juga adanya pengaruh faktor bawaan. Connor \& Davidson (Stuntzner \& Hartley, 2015) menyatakan pemahaman tentang resiliensi individu juga harus dilakukan dengan memahami pula bagaimana kondisi lingkungan tempat individu tersebut bertumbuh dan berkembang semasa hidupnya. Resiliensi tidak dilihat sebagai atribut yang pasti atau keluaran yang spesifik melainkan sebaliknya sebagai sebuah proses dinamis yang berkembang sepanjang waktu. Connor \& Davidson mengatakan bahwa resiliensi akan terkait dengan kompetensi personal, standar yang tinggi dan keuletan. Ini memperlihatkan bahwa seseorang merasa sebagai individu yang mampu mencapai tujuan dalam situasi kemunduran atau kegagalan, percaya pada diri sendiri, memiliki toleransi terhadap afek negatif dan tegar dalam menghadapi stres, cepat melakukan coping terhadap stres, menerima perubahan positif dan mampu beradaptasi serta adanya pengaruh spiritual. (Stuntzner \& Hartley, 2015) Individu yang resilien dapat mengatasi perasaan dengan baik saat ditimpa masalah, saat individu merasa sakit atau stres maka individu tersebut dapat kembali dan menemukan cara untuk keluar dengan baik dari masalah yang dihadapi serta bangkit kembali setelah terjatuh dan tidak putus asa sehingga dapat menjadi lebih baik dari yang sebelumnya.

Beberapa penelitian terkini mulai memperluas penelitian resiliensi ke ranah keluarga seperti menurut ( $F$ Walsh, 2013) dalam tulisannya dinyatakan bahwa keluarga merupakan suatu sistem utama dalam membentuk individu, setiap keluarga akan menghadapi kendala atau resiko namun diharapkan keluarga dapat mengatasi kendala tersebut dengan baik. Hal ini juga yang dialami oleh orangtua yang memiliki anak postlingual deafness, ketika mereka mengetahui anak mereka mengalami penurunan pendengaran dan hal ini menjadi tekanan bagi mereka, resiliensi ini sangat penting dalam membantu individu untuk mengatasi kesulitan yang muncul setiap hari (Froma Walsh, 2016). Dengan meningkatkan resiliensi, maka individu akan mampu mengatasi kesulitan apapun yang muncul di dalam kehidupan ini. Resiliensi juga merupuakan kunci sukses untuk memperoleh kesejahteraan dalam hidup (Criss et al., 2015). 
Menurut (Diener \& Chan, 2011) kesejahteraan subjektif didefinisikan sebagai evaluasi individu terhadap kehidupannya yang berkaitan dengan komponen kognitif dan afektif yang mencakup kepuasan hidup, afek positif dan afek negatif. (Schimmel, 2009) menyatakan bahwa kesejahteraan subjektif adalah hasil evaluasi mengenai kualitas hidup dengan mengakumulasikan dinamika emosi yang ada di dalam dirinya. Kesejahteraan subjektif dapat dialami oleh siapa saja, tanpa terkecuali orangtua yang memiliki anak postlingual deafness. Menurut (Kahneman \& Deaton, 2010), kesejahteraan subjektif pada orangtua sangat dipengaruhi oleh keadaan keluarga, semakin baik kondisi keluarga maka semakin baik pula kesejahteraan yang dirasakan orangtua dan salah satu faktor yang menjadi penentu kebahagiaan keluarga adalah anak.

Semua pasangan suami istri ingin memiliki anak yang terlahir dengan kondisi normal, namun terdapat beberapa keluarga yang memiliki anak berkebutuhan khusus, seperti anak yang mengalami penurunan pendengaran. Ketidakmampuan anak dalam mendengar inilah yang menjadi permasalahan dan menimbulkan stres serta perasaan marah, kecewa, terkejut dan kuatir pada orangtua. Dalam hal ini, memiliki anak postlingual deafness dinilai sebagai suatu pengalaman yang kurang menyenangkan karena kondisi anak yang tidak sesuai dengan harapan. Pada orangtua yang memiliki anak postlingual deafness, beban yang terjadi karena adanya perubahan-perubahan dalam keluarga dapat menyebabkan resiko terjadi rendahnya kesejahteraan subjektif pada orangtua. Orangtua sebagai pendidik dan pengasuh utama diharapkan dapat mengetahui kemampuan dirinya dalam mendidik dan mengasuh anaknya yang postlingual deafness sehingga dapat sejahtera dalam hidupnya dan juga dapat memaksimalkan kemampuan yang dimiliki oleh anaknya. Oleh karenanya pada penelitian ini memfokuskan apakah terdapat perbedaan antara resiliensi dan kesejahteraan subjektif pada Ayah dan Ibu yang memiliki anak postlingual deafness.

\section{Metode}

Penelitian ini menggunakan metode kuantitatif dengan pendekatan studi komparatif. Penelitian komaratif merupakan penelitian yang dimaksudkan untuk mengetahui perbedaan dua kelompok atau lebih (Neuman, 2014). Peneliti menggunakan metode komparatif ini dengan maksud untuk mengetahui perbedaan antara Ayah dan Ibu yang memiliki anak postlingual deafness. Partisipan dalam penelitian ini adalah 336 orangtua (168 Ayah dan $168 \mathrm{Ibu}$ ) yang memiliki anak postlingual deafness, merupakan Ayah dan Ibu kandung dari anak postlingual deafness, tinggal bersama pasangannya dan anaknya yang mengalami postlingual deafness, mampu berkomunikasi secara lisan dan tulisan menggunakan bahasa Indonesia yang baik, berdomisili di Jawa Barat.

Instrumen yang digunakan untuk mengukur resiliensi pada partisipan ialah dengan menggunakan Connor Davidson Resilience Scale (CD-RISC) yang telah dimodifikasi ke dalam bahasa Indonesia oleh Lamsinar \& Ratna (2011) dan diperoleh koefisien validitas aitem dengan nilai minimum sebesar 0,30 dan nilai maksimum sebesar 0,70 serta reliabilitas sebesar 0,87 . Instrumen ini terdiri dari 25 pernyataan. Masingmasing aitem mempunyai rentang skala likert antara 0 hingga 4 dengan rentang skor dari skala ini antara 0 100. Semakin tinggi skor, maka semakin tinggi tingkat resiliensi, begitupula sebaliknya. Instrumen yang digunakan dalam mengukur kesejahteraan subjektif pada partisipan dikonstruksi oleh peneliti berdasarkan dari teori Diener. Instrumen ini terdiri dari 30 pernyataan dan sebelum dilakukan penyebaran instrumen kepada partisipan, peneliti melakukan analisis aitem dan diperoleh koefisien validitas aitem dengan nilai minimum sebesar 0,34 dan nilai maksimum sebesar 0,63 serta reliabilitas sebesar 0,91 .

Analisa data yang digunakan adalah independen sample T-Test atau uji t sampel bebas yang digunakan untuk menguji perbedaan rata-rata dari dua kelompok sampel yang independen. Peneliti menggunakan analisa data ini karena penelitian ini bertujuan untuk melihat perbedaan resiliensi dan kesejahteraan subjektif pada Ayah dan Ibu yang memiliki anak postlingual deafness. 


\section{Hasil dan Pembahasan}

Tabel 1. Uji Normalitas

\begin{tabular}{llll}
\hline Variabel & \multicolumn{3}{c}{ Komogorov-Smirnov } \\
\cline { 2 - 4 } & Mean & Df & Sig. \\
Resiliensi & 63.50 & 334 & 0.878 \\
Kesejahteraan & 74.67 & 334 & 0.894 \\
Subjektif & & & \\
\hline
\end{tabular}

Hasil uji normalitas pada tabel 1 menunjukkan bahwa data penelitian ini normal karena memiliki signifikansi untuk resiliensi 0.878 ( $\mathrm{p}>0.05)$ dan signifikansi kesejahteraan subjektif 0.894 (p.0.05).

Tabel 2. Uji Homogenitas

\begin{tabular}{llcc}
\hline \multicolumn{1}{c}{ Variabel } & & Levene's Test for Equality of Variances \\
& & F & Sig. \\
\hline Resiliensi & Equal variances assumed & 0.374 & 0.541 \\
& $\begin{array}{l}\text { Equal variances not } \\
\text { assumed } \\
\text { Kesejahteraan Subjektif }\end{array}$ & & \\
& $\begin{array}{l}\text { Equal variances assumed } \\
\text { Equal variances not } \\
\text { assumed }\end{array}$ & 0.019 & 0.890 \\
& & & \\
\hline
\end{tabular}

Berdasarkan table 2 uji homogenitas, menunjukkan nilai $\mathrm{F}$ resiliensi sebesar 0.374 dan p sebesar 0.541 serta nilai $\mathrm{F}$ kesejahteraan subjektif sebesar 0.019 dan p sebesar 0.890 , yang berarti data penelitian ini memiliki varians data antara kelompok Ayah dan kelompok Ibu adalah homogen atau sama. Oleh karenanya pada penelitian ini, penafsiran tabel output independent sample $\mathrm{T}$ Test menggunakan nilai yang terdapat pada tabel equal variance assumed.

Tabel 3. Uji Hipotesis

\begin{tabular}{lccccccc}
\hline Variabel & Group & Number & t & Sig. & $\begin{array}{c}\text { Mean } \\
\text { Difference }\end{array}$ & \multicolumn{2}{c}{$\begin{array}{c}\text { 95\% Confidence } \\
\text { Interval of the } \\
\text { Difference }\end{array}$} \\
& & & & & & & \\
Lower & Upper \\
\hline Resiliensi & Ayah & 168 & -5.735 & 0.000 & -12.238 & -16.435 & -8.041 \\
& Ibu & 168 & & & & & \\
$\begin{array}{l}\text { Kesejahteraan } \\
\text { Subjektif }\end{array}$ & Ayah & 168 & -19.651 & 0.000 & -29.929 & -32.924 & -26.933 \\
& Ibu & 168 & & & & & \\
\hline
\end{tabular}

Hipotesis penelitian:

H0: Tidak ada perbedaan yang signifikan antara hasil resiliensi dan kesejahteraan subjektif antara Ayah dan Ibu yang memiliki anak postlingual deafness.

Ha: Terdapat perbedaan yang signifikan antara hasil resiliensi dan kesejahteraan subjektif antara Ayah dan Ibu yang memiliki anak postlingual deafness. 
Berdasarkan tabel diatas diketahui nilai sig. (2-tailed) untuk resiliensi sebesar $0.000<0.05$, maka sebagaimana dasar pengambilan keputusan dalam uji independent sampel t test dapat disimpulkan bahwa H0 ditolak dan Ha diterima. Dengan demikian dapat disimpulkan bahwa ada perbedaan yang signifikan antara hasil resiliensi dan kesejahteraan subjektif antara Ayah dan Ibu yang memiliki anak postlingual deafness. Selanjutnya dari tabel di atas diketahui nilai mean difference resiliensi adalah sebesar -12.238 dan selisih perbedaan adalah -16.435 sampai -8.041 serta mean difference kesejahteraan subjektif sebesar -29.929 dan selisih perbedaan adalah -32.924 sampai -26.933 (95\% confidence interval of the difference lower upper).

Diketahui t hitung resiliensi adalah sebesar $5.735>\mathrm{t}$ tabel 1.967, t hitung kesejahteraan subjektif adalah sebesar $19.651>\mathrm{t}$ tabel 1.967, maka berdasarkan dasar pengambilan keputusan melalui perbandingan $\mathrm{t}$ hitung dan $\mathrm{t}$ tabel, dapat disimpulkan bahwa H0 ditolak dan Ha diterima, yang berarti ada perbedaan ratarata resiliensi dan rata-rata kesejahteraan subjektif antara Ayah dan Ibu yang memiliki anak postlingual deafness.

Berdasarkan hasil penelitian diketahui bahwa terdapat perbedaan yang signifikan pada resiliensi dan kesejahteraan subjektif antara Ayah yang memiliki anak postlingual deafness dengan Ibu yang memiliki anak postlingual deafness. Berdasarkan rata-rata resiliensi yang terlihat dalam kelompok, kelompok Ayah yang memiliki anak postlingual deafness memiliki skor yang lebih tinggi dibandingkan dengan kelompok Ibu yang memiliki anak postlingual deafness, hal ini dikarenakan mereka memiliki perasaan yang kuat serta konsisten walaupun dalam situasi yang tidak menguntungkan, mereka juga mudah dalam melakukan coping terhadap stres yang dialami serta memiliki penerimaan positif terhadap perubahan yang ada khususnya pada anak mereka yang mengalami kemunduran dalam pendengaran. Berbeda dengan Ibu yang memiliki anak postlingual deafness, mereka memperoleh skor yang rendah pada resiliensi karena ketika mengetahui bahwa anak mereka mengalami kemunduran dalam pendengaran, mereka membutuhkan waktu yang cukup lama untuk menerima kenyataan ini bahkan untuk melakukan coping terhadap stres yang dialami serta bangkit kembali untuk bertahan dan kembali menata hidupnya dan juga mendidik anaknya yang mengalami kemunduran dalam pendengaran.

Hasil penelitian ini sejalan dengan penelitian yang dilakukan oleh (Khan, M.A., Kamaran, R., \& Ashraf, 2017) yang meneliti mengenai resiliensi, perceived social support dan locus of control pada Ibu yang memiliki anak autis dengan Ibu yang memiliki anak normal, hasil yang diperoleh adalah bahwa terdapat perbedaan resiliensi pada Ibu yang memiliki anak autis dengan Ibu yang memiliki anak normal, dimana resiliensi pada Ibu yang memiliki anak autis lebih rendah dibandingkan dengan Ibu yang memiliki anak normal. Penelitian lain juga yang sejalan dengan hasil penelitian ini adalah penelitian yang dilakukan oleh (Ebrahimi et al., 2015) yang meneliti mengenai stigma pada Ibu yang memiliki anak tunarungu, kesimpulan yang dihasilkan adalah setengah dari Ibu yang memiliki anak tunarungu merasa malu memiliki anak tunarungu karena adanya stigma negatif di masyarakat mengenai kondisi ketunarunguan anaknya. Stigma negatif ini juga dapat memberikan tekanan dan tidak kuat dalam menghadapi kenyataan bahwa mereka memiliki anak berkebutuhan khusus sehingga akan berdampak buruk terhadap pengasuhan anaknya. Adanya kesamaan hasil penelitian ini dengan penelitian sebelumnya dapat dijelaskan bahwa secara global bagi Ibu yang memilliki anak dengan kebutuhan khusus, memiliki tekanan yang besar untuk menerima kenyataan bahwa anak mereka termasuk yang berkebutuhan khusus baik dari keluarga maupun masyarakat, ditambah mereka pun harus melakukan penyesuaian-penyesuaian dalam proses pengasuhan pada anak mereka yang mengalami kebutuhan khusus. Pada penelitian ini, Ibu yang memiliki anak postlingual deafness berusaha melakukan penyesuaian dalam proses pengasuhan karena pada awalnya anak mereka mendengar dengan normal namun dikarenakan dalam fungsi pendengarannya mengalami penurunan seperti yang dilakukan oleh kelompok Ibu dalam penelitian ini, mereka belajar menggunakan bahasa isyarat guna dapat berkomunikasi dengan anaknya dan disisi lain mereka pun mengajarkan bahasa isyarat tersebut kepada anaknya yang mengalami postlingual deafness.

Pada hasil kesejahteraan subjektif, berdasarkan rata-rata yang terlihat dari kelompok, kelompok Ayah yang memiliki anak postlingual deafness memperoleh skor yang lebih tinggi dibandingkan dengan kelompok Ibu yang memiliki anak postlingual deafness. Kesejahteraan subjektif merupakan salah satu komponen yang dapat menentukan sikap positif pada individu dalam melihat dunianya. Cara pandang orangtua mengenai hambatan pada anaknya dapat mempengaruhi aspek-aspek utama dan pribadi kehidupan mereka, bila Ayah maupun Ibu yang memiliki anak postlingual deafness melihat hambatan pada anak mereka sebagai hal yang negatif pada kehidupan keluarganya, maka dapat membuat kesejahteraan subjektif yang rendah, begitupula sebaliknya (Cummins et al., 2014) (Kortte et al., 2010) menyatakan bahwa orangtua memiliki harapan bagi 
anaknya namun harapan tersebut dipengaruhi oleh kondisi atau keadaan anak mereka. Bagi orangtua yang memiliki anak dengan kebutuhan khusus, mereka merasa cemas akan masa depan anak mereka, cara orangtua memandang ketidakmampuan anaknya tersebut juga mempengaruhi kesejahteraan subjektif mereka. Hasil penelitian ini sejalan dengan penelitian yang dilakukan oleh (Diener, 2009) yang menyatakan bahwa secara personality, laki-laki lebih memiliki kesejahteraan subjektif yang tinggi apabila dibandingkan dengan wanita. Pada laki-laki lebih banyak mengungkapkan afek positif sedangkan pada wanita lebih cenderung mengungkapkan afek negatif.

Pada penelitian ini kelompok Ayah memiliki rata-rata kesejahteraan subjektif yang tinggi dikarenakan mereka merasa puas dengan dukungan yang diberikan oleh pasangannya, menerima kondisi anaknya yang postlingual deafness, puas dengan pekerjaan yang dilakukannya saat ini dan merasakan bahwa pendapatan yang diterima saat ini cukup untuk memenuhi kebutuhan keluarganya dan kebutuhan tambahan (seperti terapi, les) bagi anak mereka yang mengalami postlingual deafness. Berbeda dengan kelompok Ibu yang kurang merasa puas dengan dukungan yang mereka terima. Menurut kelompok Ibu, mereka puas dengan dukungan dari pasangan namun mereka kurang puas menerima dukungan dari keluarga besarnya, bahkan pada saat awal anak mereka mengalami penurunan pendengaran, keluarga besar cenderung menyalahkan mereka akan kondisi anaknya tersebut. Selain itu juga adanya stigma negatif dari masyarakat mengenai anak berkebutuhan khusus itu sendiri membuat Ibu memandang negatif terhadap kesejahteraan dirinya. Penelitian lain juga menyatakan bahwa rendahnya kesejahteraan subjektif pada Ibu yang memiliki anak berkebutuhan khusus dikarenakan Ibu mengalami kesulitan saat mengasuh anaknya sehingga Ibu mengerahkan seluruh sumber daya pribadinya dan hal ini dapat membuat rendahnya kesejahteraan pada Ibu (Werner \& Shulman, 2013). Selain itu menurut (Diener, 2009) adanya penilaian negatif dalam hidup dapat mempengaruhi kesejahteraan subjektif individu.

\section{Kesimpulan}

Berdasarkan hasil dan pembahasan dalam penelitian ini dapat disimpulkan bahwa terdapat perbedaan yang signifikan pada resiliensi dan kesejahteraan subjektif antara Ayah dengan Ibu yang memiliki anak postlingual deafness. Menurut rata-rata yang terlihat dalam kelompok, kelompok Ayah yang mempunyai anak postlingual deafness memiliki skor yang lebih tinggi dalam resiliensi maupun kesejahteraan subjektif dibandingkan dengan kelompok Ibu. Perbedaan ini disebabkan karena pada kelompok Ayah lebih cenderung memiliki perasaan yang kuat serta mereka juga mudah dalam melakukan coping ketika menghadapi tekanan khususnya saat mengetahui bahwa anak mereka mengalami postlingual deafness. Kelompok Ayah juga mempunyai cara pandang yang lebih positif terhadap kehidupannya termasuk mengenai kondisi anaknya yang mengalami postlingual deafness. Berbeda dengan kelompok Ibu yang memiliki anak postlingual deafness, mereka cenderung membutuhkan waktu yang lebih lama untuk menerima kondisi anaknya serta bangkit kembali untuk bertahan menjalani hidupnya. Disamping itu, mereka juga kurang puas dengan dukungan yang diterima dari keluarga besar dan stigma dari masyarakat, sehingga hal ini yang membuat Ibu memiliki kesejahteraan subjektif yang rendah.

Resiliensi dan kesejahteraan subjektif yang dimiliki orangtua, baik Ayah maupun Ibu sangat berperan penting dalam proses pengasuhan dan pendidikan anak mereka yang mengalami postlingual deafness. Oleh karenanya sangat disarankan bagi pihak sekolah untuk bekerjasama dengan professional seperti psikolog maupun konselor dalam merancang intervensi guna membantu meningkatkan resiliensi dan kesejahteraan subjektif terutama bagi kelompok Ibu yang memiliki anak postlingual deafness. Selain itu, bagi peneliti selanjutnya disarankan untuk dapat meneliti faktor-faktor lain disamping resiliensi yang dapat mempengaruhi kesejahteraan sujektif terutama bagi orangtua yang memiliki anak berkebutuhan khusus.

\section{Referensi}

Amini, F., Alizadeh, H., \& Rezaee, O. (2012). Comparison of executive-neurological functions between addicted adults and normal adults. Annals of Biological Research, 3(1), 415-421.

Anderson, L.W., \& Krathwohl, D. . (2010). Kerangka Landasan untuk Pembelajaran, Pengajaran dan Asesmen (Revisi Taksonomi Pendidikan Bloom). Pustaka Pelajar.

Azari, Z., \& Mohammadi, M. (2016). Compare resilience of families with mentally retarded children and family with normal children. Journal of Administrative Management, Education and Training, 12, 119-127.

Criss, M. M., Henry, C. S., Harrist, A. W., \& Larzelere, R. E. (2015). Interdisciplinary and innovative 
approaches to strengthening family and individual resilience: An introduction to the special issue. Family Relations, 64(1), 1-4.

Cummins, R. A., Li, N., Wooden, M., \& Stokes, M. (2014). A demonstration of set-points for subjective wellbeing. Journal of Happiness Studies, 15(1), 183-206.

Diener, E. (2009). Subjective well-being. In The science of well-being (pp. 11-58). Springer.

Diener, E., \& Chan, M. Y. (2011). Happy people live longer: Subjective well- being contributes to health and longevity. Applied Psychology: Health and Well- Being, 3(1), 1-43.

Ebrahimi, H., Mohammadi, E., Mohammadi, M. A., Pirzadeh, A., Mahmoudi, H., \& Ansari, I. (2015). Stigma in mothers of deaf children. Iranian Journal of Otorhinolaryngology, 27(79), 109.

Findler, L., Jacoby, A. K., \& Gabis, L. (2016). Subjective happiness among mothers of children with disabilities: The role of stress, attachment, guilt and social support. Research in Developmental Disabilities, 55, 44-54.

Gardiner, E., \& Iarocci, G. (2012). Unhappy (and happy) in their own way: A developmental psychopathology perspective on quality of life for families living with developmental disability with and without autism. Research in Developmental Disabilities, 33(6), 2177-2192.

Kahneman, D., \& Deaton, A. (2010). High income improves evaluation of life but not emotional well-being. Proceedings of the National Academy of Sciences, 107(38), 16489-16493.

Khan, M.A., Kamaran, R., \& Ashraf, S. (2017). Resilience, Perceived Social Support and Locus of Control in Mothers of Children with Autism vs Those Having Normal Children. Pakistan Journal of Professional Psychology: Research and Practice, 8(1), 1-13.

Kimiaye, S. A., Mehrabi, H., \& Mirzaei, Z. (2010). Comparing The Mental Health of Parents with Educable Mentally Retarded Children of Mashhad. Studies of Education and Psychology, 11(1), 261-278.

Kortte, K. B., Gilbert, M., Gorman, P., \& Wegener, S. T. (2010). Positive psychological variables in the prediction of life satisfaction after spinal cord injury. Rehabilitation Psychology, 55(1), 40.

Monjezi, Z., \& Naderi, F. (2016). The Comparison Between Resilience, Responsibility and Subjective WellBeing (SWB) amongst Male and Female Physicians in Ahvaz, Iran. Soc. Sci, 50(1), 9.

Norlin, D., \& Broberg, M. (2013). Parents of children with and without intellectual disability: couple relationship and individual well- being. Journal of Intellectual Disability Research, 57(6), 552-566.

Santrock, J. W. (2012). Life-span Development. Mc Graw-Hill.

Schimmel, J. (2009). Development as happiness: The subjective perception of happiness and UNDP's analysis of poverty, wealth and development. Journal of Happiness Studies, 10(1), 93-111.

Seligman, M. E. P., Ernst, R. M., Gillham, J., Reivich, K., \& Linkins, M. (2009). Positive Education: Positive Psychology and Classroom Interventions. Oxford Review of Education, 35(3), $293-311$.

Stuntzner, S., \& Hartley, M. (2015). Family Resilience Following Disability: Enhancing Counselors' Skills. Proceedings of the 2015 American Counseling Association Conference, Orlando, FL.

Turnbull, A. A., Rutherford, H., Wehmeyer., M. L., \& Shogren, K. A. (2013). Exceptional Lives: Special Education in Today's Schools. Pearson.

Walsh, F. (2013). Community-Based Practice Applications of A Family Resilience Framework. Springer.

Walsh, F. (2016). Family resilience: A developmental systems framework. European Journal of Developmental Psychology, 13(3), 313-324.

Werner, S., \& Shulman, C. (2013). Subjective well-being among family caregivers of individuals with developmental disabilities: the role of affiliate stigma and psychosocial moderating variables. Research in Developmental Disabilities, 34(11), 4103-4114.

WHO. (2019). No Title. https://www.who.int/news-room/fact-sheets/detail/deafness-and-hearing-loss

Yusuf, S. (2012). Psikologi perkembangan anak \& remaja. PT Remaja Rosdakarya. 